\title{
Internationalization Strategies and Policies in Second-Tier Higher Education Institutions
}

\author{
Hans de Wit, Miri Yemini and Randall Martin
}

\section{Introduction}

A significant number of studies (Altbach and Knight 2007; Beerkens et al. 2010; De Wit 2013a; Deardorff and Jones 2012) indicate growing support for internationalization in higher education in recent years. According to the fourth Global Survey of International Association of Universities (Egron-Polak and Hudson 2014), 89 \% of universities worldwide claim to have an institutional policy or to have implemented internationalization within their overall strategy, and $22 \%$ are preparing an internationalization strategy.

Indeed, internationalization is transforming from a reactive issue to a proactive, strategic one; from added value to mainstream. As such, its focus, scope and content evolved substantially. This growing interest has translated into active development of policies, programs, and infrastructure at institutional, local, and national levels, as well as a call for a more comprehensive approach to and action on internationalization in higher education (Hudzik 2011). Moreover, with the perception of internationalization as critical to higher education institutions, differences in the respective colleges and universities' ability to internationalize and in their scope and intensity of internationalization may influence their competitiveness and even survival (Cohen et al. 2014). While researchers generally accept Jane Knight's definition of international-

\footnotetext{
H. de Wit

Centre for Higher Education Internationalisation (CHEI),

Universita Cattolica Sacro Cuore, Milan, Italy

e-mail: j.w.m.de.wit@hva.nl

M. Yemini ( $\square)$

School of Education, Tel Aviv University, Ramat Aviv, Tel Aviv, Israel

e-mail: miriye@post.tau.ac.il

R. Martin

British Columbia Council for International Education (BCCIE), Vancouver, Canada

e-mail: martin@bccie.bc.ca
}

(C) The Author(s) 2015

A. Curaj et al. (eds.), The European Higher Education Area,

DOI 10.1007/978-3-319-20877-0_9 
ization as "the process of integrating an international, intercultural, or global dimension into the purpose, functions or delivery of post-secondary education" (Knight 2004, p. 11), the concept itself has expanded over the years and become rather broad and diverse, involving different stages, meanings, and rationales by country and region. ${ }^{1}$ While most of the historical studies on internationalization in higher education focus on research universities, in the last decade, several important efforts were made to address internationalization in different types of higher education institutions - mainly in community colleges in the US (Manns 2014; Romano 2002).

Indeed, internationalization's mainstreaming results in its expansion beyond the traditional scope of research-oriented universities, including other types of education providers: in particular community colleges, applied sciences schools, and other institutions that typically proliferated with education's global massification trends and the rising public access to higher education (Yemini et al. 2014a). Research into internationalization in such 'second-tier' 2 institutions is lacking, with the exception of a few focused studies (De Wit 2011; Maringe 2009; Raby and Valeau 2007; Waechter 1999; Yemini et al. 2014a). The present study aims to characterize the nature of internationalization within 'second-tier' higher education institutions in Israel, the Netherlands, and Canada, describing the process on national, regional, and institutional levels. Such institutions, which comprise a substantial part of the higher education sector, distinguish themselves from 'research universities' by means of a vocational and professional focus on under-graduate teaching for bachelor or associate degrees and a local, provincial, or national scope in the employability their graduates are trained for and the research efforts they undertake. Moreover, these institutions are generally characterized as younger and more entrepreneurial in comparison to research-oriented universities (Yemini et al. 2014b).

\section{Context}

\subsection{Internationalization in Higher Education}

In most countries, internationalization has come to comprise an increasingly important element of higher education and of the academic enterprise. Individual

\footnotetext{
${ }^{1}$ For an overview of internationalization in higher education, see Deardorff et al. (2012). For a debate about the need to rethink internationalization (see International Association of Universities 2012; De Wit 2013b).

${ }^{2}$ In this study, we refer to 'second tier' higher education institutions as defined by Arum et al. (2007), for example. Indeed, the term lacks a singular, clear-cut definition and sometimes may induce controversial responses as it fosters classification based on traditional, conservative measures. We choose to use this term to describe a complex array of institutions in different countries that differ significantly from one another in their fundamental characteristics; thus, the full array of their respective characterizations is difficult to capture in one term. Notably, therefore, we use the term, 'second tier institution' in this study in an exclusively technical manner, not in any normative sense.
} 
universities vary in their cross-border activities and their capacity to take advantage of global pressures and forces (Marginson 2007; Stromquist 2007). Increasingly, higher education institutions' management strive to internationalize their establishments (De Wit 2002; Hudzik 2011), while governments invest more resources in this process. De Wit (2002) details the rationales behind such institutional and governmental internationalization efforts, which include long-term or immediate economic benefits; national political benefits involving security, stability, peace, and ideological influence; an academic quest to meet international standards of teaching, research, and service; and quality of life improvements that result from learners' socio-cultural integration. Knight (2004) addresses the transformation in rationales for internationalization that took place in the recent decade from socio-cultural and academic justifications to mainly economic and political ones, including the concerns of aging populations and labour market development. Given this complex set of motivations for internationalization, diverse academic institutions may differ in their incentives to internationalize (Stier 2004); hence, comprehensive comparative analysis is necessary in understanding this phenomenon, especially within the more recently internationalizing second-tier educational institutions.

\subsection{Second-Tier Higher Education Institutions}

Since World War II, higher education systems have expanded rapidly and have been transforming organizationally. Researchers documented a tremendous growth in the number of students and the diversification of institutions of higher learning, as well as the massification of higher education (e.g. Teichler 2004). Usually, firstand second-tier institutions differ in their selectivity, curriculum, administration, cost, academic versus practical orientation, and prestige (Shavit et al. 2004, August). Despite the tremendous variations in the types of second-tier institutions (including community colleges, universities of applied sciences, and other academic and vocational colleges), as discussed in the definition of the term above (see footnote 2), such colleges are generally believed to open the gates of higher education to previously excluded social groups, thus enabling diversity. For example, four-year colleges in the US and some primarily two-year colleges in Canada are considered less prestigious than the elite or selective universities, but offer similar study fields and grant academic degrees. These institutions offer mainly vertical expansions, offering access to 'less successful' members of the same populations already being served by top-tier universities. Other newly-established institutions do not grant academic degrees (such as community colleges in the US) or take the form of vocational or semi-professional under-graduate training (e.g., the German Fachhochschulen). These institutions are expected to cater to new populations of students, thereby expanding student diversity (Ayalon and Yogev 2006).

Some (particularly European) countries have explicitly binary higher education systems comprised of universities and colleges of applied sciences (such as Austria, 
Germany, Belgium, and the Netherlands). In other countries, the differentiation is less stark. The status of the degrees such institutions grant is debated, and some countries (such as the US and Canada, as well as some developing economies) have initiated policies aimed at strengthening the vocational and professional dimension in higher education. In conjunction, resistance has emerged in many developing countries to second-tier higher education that is considered of lower status and prestige; the proliferated use of the label 'university' seems to maintain perceptions that do not always accurately reflect reality.

In summary, the definition of second-tier institutions is vague and their classification is diverse, evolving and with no clear direction. Although clear definitions and statistics are difficult to provide in most countries, these institutions comprise a substantive part of the higher education sector, tend to be vocationally and professionally oriented, focus predominantly on under-graduate teaching, offer mainly bachelor or associate degrees, and research issues of a more local or national scope.

\subsection{Internationalization in Second Tier Institutions}

In a study analysing the internationalization efforts of community colleges of different kind in US, Harder (2010) states:

Internationalization activity in higher education is not a new phenomenon. There is, however, a growing movement toward a global knowledge economy and higher demand for employees with international experience has resulted in unprecedented internationalization efforts in higher education. Colleges recognize they must provide students with skills to succeed in globally integrated economies, culturally diverse societies, and multinational organizations (153).

Internationalization in particular seems less prominent in second-tier higher education institutions for several reasons. These reasons include the relatively less developed research programs at such institutions (indeed, research often provides an international platform for collaborative teaching and learning); inadequate financial and other resources; and sometimes also a lack of prestige and academic reputation, which hinders and challenges the development of international connections (Yemini et al. 2014a). Nevertheless, the barriers to internationalization are not sector-specific. Thus, community colleges may experience the same obstacles as other institutions, and the differences are usually a matter of degree.

In the current study, we employed secondary sources including a screening of scholarly publications and policy documents, as well as media analysis, combined with our own profound academic and hands-on experiences in research and implementation of internationalization in our respective countries, to develop a joint comparative analysis of internationalization trends in second-tier institutions in the Netherlands, Israel, and Canada. The comparison between those three OECD countries, located in different geographic regions and representing huge educational diversity, allows us to comprise a novel and interesting framework that will shape the future discourse on internationalization. We continue by briefly presenting the 
higher education system in each of these three countries, accompanied by analysis of the internationalization trends practiced in each of the countries' second-tier institutions. We then conclude with comparative remarks and recommendations.

\section{Case Studies: Israel, the Netherlands and Canada}

\subsection{Israel}

\subsubsection{The Israeli Higher Education System}

Of Israel's approximately eight million citizens, a Jewish population forms the national majority of roughly $80 \%$ and Palestinian-Arabs constitute a national minority of $20 \%$. The Israeli higher education system has grown dramatically since the early 1990s, from 70,000 students two decades ago to over 300,000 in 2014, and from just seven universities and several colleges in the 1990s to sixty-six institutions currently spread nation-wide. Until the 1980s, Israel's post-secondary public education system was divided into the academic branch - consisting of the seven Israeli research universities - and the non-academic branch that encompassed all other academies, such as teachers' training seminars. During the last three decades, most non-academic branches were upgraded to fully-recognized academic, degree-granting colleges. These colleges, scattered nation-wide, range in size from around 500-20,000 students.

Despite the expansion in the number of institutions, the higher education system in Israel suffered substantial budget cuts in the past decade. Reduced government funds, new immigration patterns, a weak local economy, and strong national economic initiatives have changed the political context in which higher education institutions operate, leading them to adopt more competitive strategies (Oplatka 2002). Thus, the colleges started to compete for students not only with other colleges, but also with research universities. Yet, despite recent budget cuts, accessibility to higher education expanded in recent years. Public attention has focused on the positive social aspects of extending higher education possibilities to a broader population. The Council for Higher Education (CHE), which is responsible for educational governance and policy, meanwhile, tends to view the expansion of Israeli higher education in the last decade as consisting of two stratified layers of institutions: the 'first tier' of universities, versus the 'second tier' of colleges, based on the research versus teaching orientation and the universities' exclusive ability to grant doctoral and post-doctoral degrees. This categorization meets increasing opposition from the leading colleges (especially from the private and more elitist institutions), which claim to have achieved the same status as research universities in regulation and funding.

From the early days of the Israeli higher education system, international academic cooperation has been one of its soundest and best-established foundations. Due to Israel's geographical regional isolation and the foreign academic origins of 
the founders of the Technion and the Hebrew University of Jerusalem (the first Israeli higher education institutions), the Israeli academy has always been interwoven into the American and European academic world. Significant numbers of Israeli researchers and institutes have participated in international or bilateral research and research groups; indeed, these tight ties, alongside Israeli academia's ability to be at the cutting edge of research in many areas, strengthened the international status of the Israeli academy. However, Israeli academia's main focus has been on research and participation in various international forums, either in scientific exploration or in diplomatic and political fields. Israeli research students are often granted advanced international study posts or grants for postdoctoral research abroad, mostly relying on personal ties or occasional bilateral agreements between academic institutions in Israel and abroad (Yemini and Ben-Artzi 2013).

\subsubsection{Internationalization at Second-Tier Israeli Higher Education Institutions}

In Israel, second-tier higher education institutions exploit internationalization to elevate their status and expand in their study programs (Yemini et al. 2014a). As in other countries like Norway (Kyvik 2002), the Netherlands (De Wit 2012) or the US (Coelen 2014), structural reforms in the Israeli higher education system tend to encourage second-tier institutions to attain a first-tier status through internationalization, among other initiatives.

Internationalization was largely absent from the agenda of Israeli second-tier academic institutions until the last decade, as until that point, these institutions were busy developing independent programs and establishing their national status as independent, stand-alone academic institutions. Given the CHE's financial guidelines that exclude international students from enrolling in funded programs and a complicated geo-political situation that largely discourages international students, the common incentives for higher education institutions to develop internationalization in other countries have been inapplicable in Israeli academia-particularly within second-tier colleges. Nevertheless, in the last few years, two major trends can be traced in this field. The first is an increasing participation of academic colleges in EU programs - mainly Erasmus Plus (formally Tempus) - at an even higher intensity than the participation of Israeli research universities (Yemini 2014). This occurrence results from the fact that Israel that joined Tempus in 2008 as a partner country, successfully participating in parallel as full member within the EU's research programs (Horizon 2020; see also the guidelines of the formal Framework agreements). Thus, research universities were not too enthusiastic to join less lucrative partnerships, such as those offered in the context of a Tempus partner country, which cleared out for Israeli second-tier institutions an extremely comfortable platform for international cooperation. Those entrepreneurial ventures opened up new opportunities for the colleges and fostered additional projects, programs, and partnerships with research programs in Europe and other parts of the world. 
Moreover, Israeli colleges enrol a much more diverse population than usually attends research universities. Its students hail from different sectors and communities (Jewish and Palestinian-Arab; new immigrants, and those with ethnic backgrounds from different parts of the world); thus, second-tier colleges face the need and the opportunity to develop an intercultural dimension in education, which comprises an integral part of internationalization's definition (Knight 2004). Indeed, several colleges nowadays address this challenge by presenting extensive work on developing the intercultural dimension in their aims, function, and delivery of education (Cohen et al. 2014).

Notably, Israeli college directors interviewed in a previous study by two of the authors (Yemini et al. 2014a) interpret internationalization in differing manners, depending on the characteristics of the institutions they lead (as per Knight 2004). Indeed, Yemini et al. (2014a) found that although all second-tier Israeli colleges function under strict financial constraints and strive to upgrade their status and to compete with established research universities, it seems that colleges' orientation, population and location are the most influential factors regarding their motivation to internationalize. In general, directors of colleges that are located in the country's geographical periphery seem less motivated to internationalize than directors of colleges located in Israel's centre. Engineering, arts, and humanities college directors mainly from colleges located in Israel's centre focus more prominently on global and international issues, while teacher training institutions mainly stress cross-cultural elements, generally regarding Israeli minorities, such as Palestinian Arabs and immigrants. Moreover, colleges with a high concentration of minorities might identify opportunities for social mobility through international contacts. Beyond these institutional factors, the directors' personal backgrounds were also found to significantly impact their motivation to internationalize (Yemini et al. 2014a).

In another study focused on directors of graduate programs in research universities and colleges (Yemini et al. 2014b), the global-local debate also played a prominent role in the academic discourse. This study sought to analyze the perceptions of educational administration program directors in diverse institutions and contextual settings regarding the international, global, and intercultural dimensions in their programs' aims, functions and delivery. More specifically, the study undertook a selective assessment of 12 program directors from various Israeli higher education institutions including research universities, Jewish secular and religious colleges, and Palestinian-Arab colleges. Semi-structured, in-depth interviews were conducted with program heads to uncover their motivation to engage their departments in internationalization processes. It was found that the main themes program directors mention regarding their motivation to internationalize can be broken down into several categories, namely (a) the purpose of the program in terms of preparation of graduates to local or global work place; (b) the program's relations with the institution's goals in terms of research or teaching orientation; and (c) the different meanings of internationalization as these leaders perceive them, 
especially as relating to global/international or intercultural dimensions. Additional research is needed to shed light on the motivations for and obstacles facing internationalization in second-tier institutions in particular, within the complex tension of the global-local nexus in unique socio-political settings within Israeli education system.

\subsection{Netherlands}

\subsubsection{The Dutch Higher Education System}

Like other European countries such as Austria, Belgium, Germany, and the Scandinavian states, the Netherlands has a binary system of higher education, composed of research universities and universities of applied sciences. The Netherlands has thirteen research universities, including the Open University, all of which benefit from a strong international reputation. Indeed, in the various global university rankings, all but one appear in the top 200. Moreover, Dutch research universities average very high in the rankings of national systems, regarding both their publications and other criteria.

In comparison to other countries, the Dutch applied sciences sector is quite substantial. Of the 600,000 post-secondary students in the Netherlands, over 400,000 study in the nation's approximately forty universities of applied sciences, while the rest are enrolled in the thirteen research universities.

Over the past two decades, the universities of applied sciences have undergone a merger process, in which the 400 institutions were reduced by $90 \%$. The rationale behind this merger process was to allow for an increase in the number of students in this sector (instead of expanding the research universities), so as to maintain the quality of academic education and to reduce its costs. This process resulted in the emergence of large educational conglomerates, several of which comprise over 30,000 students. Indeed, in the same period, the number of students doubled, with enrolment expanding in all areas of study.

As in Israel, differences between the research universities and applied science institutions are rather explicit. Dutch universities of applied sciences used to provide mainly undergraduate education through a four-year program that in the past would culminate in professionalized rather than academic degrees, until in 2014 the Minister of Education allowed universities of applied sciences to grant B.A. and B. Sc. degrees (parallel to the ones offered as three-year programs at the research universities). Moreover, although the universities of applied sciences have been permitted to develop masters programs, these must be self-funded and cannot compete with the subsidized and higher quality graduate programs of the research universities. Resultantly, such advanced degrees are nearly nonexistent at universities of applied sciences. 


\subsubsection{Internationalization at Second-Tier Dutch Higher Education Institutions}

Little systematic study has been carried out on the internationalization of universities of applied sciences in Europe in general and specifically in the Netherlands. The only extensive European analysis dates from fifteen years ago: Internationalisation in European Non-University Higher Education (Waechter 1999). In their introduction to this study, Bremer and Waechter state that this sector's relative newness, its lack of a research tradition, its more practical and professional orientation, its schoolish nature, and its more local mission and orientation can all explain the lag in internationalization within non-academic European higher education. Above all other explanations, Bremer and Waechter (1999, pp. 11-12) credit the structural disarray of this sector in comparison to the academic sector. Van der Wende (1999, p. 209) further explains the problems with differences in and recognition of the professional qualifications these institutions provide, as well as the diversity of the sector.

Although Waechter's (1999) study did not reach clear and univocal conclusions on whether universities of applied sciences' image of deficient internationalization was correct, this public image did lead to a rise in the volume of international activities. Most dominant among these new efforts was increasing student mobility, followed by teacher mobility. Internationalisation of the curriculum remained marginal, with the exception of those portions offered in English. There were few available international sources in the field of lifelong learning, but their policy and organization were mostly unsystematic. Student internships abroad were introduced in this period as well, but also lacked a systematic approach. Moreover, little change took place regarding the focus on foreign language teaching: English remained the dominant second foreign language, followed by the language of neighbouring countries. Moreover, partnerships were poorly developed and especially oriented towards neighbouring countries or the English-speaking countries (Waechter 1999, pp. 181-190).

Fifteen years later, some progress towards internationalization did indeed take place at these universities, but a pilot by Dutch Flemish Accreditation Organization NVAO on internationalization demonstrated that the lag behind the research universities remained. The universities of applied sciences scored lower than the academic programs on both international learning outcomes and integration of internationalization within the institutions' vision, mission statements and policy (Aerden et al. 2013).

Hence, rather than comparing these institutions' internationalization with that taking place at Dutch research universities, it is relevant to look at the specific function of the sector itself and their implications for its internationalization, and in particular for relations with the professional field. More so than universities, applied science institutions should consider this relationship with the professional field to be their underlying motive for internationalization. As Leggott and Stapleford state: "In the twenty-first century international labour market the development of employability skills and attributes through adopting international perspectives is 
essential to the enhancement of the employment prospects of students" (Leggott and Stapleford 2007, p. 133).

However, the Dutch Small to Medium-Sized Enterprise (SME) sector in particular, where the majority of the graduates of universities of applied sciences find employment, is insufficiently prepared for the worldwide knowledge economy. SME companies experience intercultural and language barriers when they operate abroad. International investments by Dutch SME-companies remain behind the EU-average, revealing numerous lost opportunities. Moreover, a study by the research group "Internationalisation and the International Professional Field" at the Hanzehogeschool Groningen mentions the lack of intercultural competencies of Dutch SMEs' staff, their insufficient knowledge of foreign countries and markets, and inadequate linguistic skills as important impediments for this sector (HanzeConnect 2008).

In contrast, in terms of student diversity, second-tier Dutch institutions are quite diversely integrated. In 2010, $14 \%$ of their student population hailed from other cultures; notably however, in the cities of Western Holland, at institutions like the Amsterdam University of Applied Sciences, this statistic is considerably higher. Indeed, in addition to the requirements from the professional field, such student diversity also yields consequences for the management of intercultural and international competencies. Hence, this situation offers a challenge, but also an opportunity for internationalization.

Ultimately, the main obstacles to internationalization at second-tier Dutch higher education institutions comprise a lack of a teaching staff that can prepare students for a more international and intercultural career, lack of opportunities to develop joint and double degrees, ambiguity regarding the identity of their peers abroad, lack of access to research funding, and lack of a clear vision on internationalization as a sector. In contrast, opportunities for the sector to enhance internationalization are diverse, including its rich experience with internships, its strong relationship with the professional field, and its diverse student population that enables virtual exchange and mobility. In developing these opportunities, the sector can build on the experience of several of its institutions, which have managed to overcome the obstacles and the lack of support from the sector. However, in order to realize these opportunities, instead of following in the footsteps of the research universities and/or relying upon Education Ministry initiatives, as two recent documents (Coelen 2014; VSNU and Vereniging Hogescholen 2014) reveal to be the case at present, the sector must develop its own targeted internationalization strategy.

\subsection{Canada}

\subsubsection{The Canadian Higher Education System}

Canada is a federation, and constitutional responsibility for higher education in Canada resides individually with the three territories and ten provinces. Each 
Canadian province and territory has its own Ministry or Ministries of Education and a separate and unique higher education system that reflects territorial, historical, organizational, and regional economic goals. As a result of this constitutional arrangement, a distinctive system of education, including higher education, has evolved in each jurisdiction. No national ministry or department of education exists, nor is there any integrated national system. When needed, national coordination and consensus are attempted most often through a body comprised of the respective provincial and territorial Education Ministers (the Council of Ministers of Education, Canada, or CMEC). Notably, moreover, five Canadian national associations coordinate their respective sectors' activities: colleges and institutes; language schools; research and teaching universities; K-12 school districts; and a coordinating 'Bureau' for international education. Federal suasion and influence over national priorities are achieved through targeted means such as science and research grants, development or contract activity, international student and faculty mobility grants, and more recently through Canada's international education strategy and a coordinated international marketing and branding exercise. Additionally and of special relevance to Canada's second-tier institutions, the federal Human Resources and Skills Development department is jointly responsible with the provinces and territories for many matters, including the inter-provincial mobility of skills and some national qualification standards.

Post-secondary or higher education is available from both government-supported and private institutions, which, through legislation, are authorized to offer degrees, diplomas, certificates, or other credentials and records of academic achievement depending upon the nature of the institution and the length of the program. Universities and university colleges - and increasingly colleges, institutes and polytechnics - focus on degree programs, but may also offer some diplomas and certificates, often in professional designations. Indeed, universities no longer comprise the only degree-granting institutions in some jurisdictions. Notably, moreover, in Canada, publicly-funded colleges and universities offer the vast majority of PSE.

Over 135 public higher education institutes and colleges exist in Canada with thousands of campuses which, depending upon the jurisdiction, may also be called public colleges, specialized institutes, community colleges, institutes of technology, career colleges, colleges of applied arts and technology, or cégeps in Quebec (collèges d'enseignement général et professionnel). The sum of these would constitute the category of second-tier institutions in the Canadian context, although the categorization of first- versus second-tier institutions is not as clear-cut in Canada as it is in the other countries under investigation in this study.

The publicly-funded colleges and institutes generally share a common value system, in that they are actively engaged in their own communities' social and economic development; they are accessible to all who want to learn and find employment; they are learner-focused and committed to students' career success; they are closely connected to employers and their requirements; they are focused on applied learning and applied research; and they are committed to internationalization to a certain extent. Indeed, this system has an international reputation for 
maintaining some of the closest connections to employers. Moreover, Canadian higher education institutions are currently implementing over $\$ 100$ million of projects in 28 countries to share their 'Education for Employment' approach.

\subsubsection{Internationalization at Second-Tier Canadian Higher Education Institutions}

The diverse landscape of second-tier institutions in Canada presents differing approaches to internationalization, with particular jurisdictions and institutions demonstrating differing challenges and successes. The relatively more 'hands-on' worldview and mandate of the second-tier sector and the historically shorter span of their programs present both an impediment and support to internationalization efforts. Additionally, the relative lack of socioeconomic reach on students in second-tier institutions, as compared to those in the first tier ones, may well compound these other existing structural challenges and impede achievement of the same level and volume of engagement and buy-in of internationalization experienced in the first tier. For example, while many second-tier institutions do well to exceedingly well in terms of international student recruitment, they have a less stellar record of achievement in sending their own students abroad: the Association of Community Colleges in Canada (ACCC 2010) suggests that in 2007/08, "only $1.1 \%$ of Canadian colleges' full-time students participated in out-of-country learning experiences" (12).

In contrast to the situation in Netherlands and Israel, in Canada, $95 \%$ of both first-tier and second-tier post-secondary institutions included internationalization in their mandate. That said, the intersection between rhetoric and budget communicates an institution's commitment (or ability to commit) to the strategy. While mission statements reinforce internationalization, awareness of internationalization among college students is much lower than at universities. The Canadian Bureau for International Education (CBIE) report, A World of Learning (2009), suggests that "where $90 \%$ of [Canadian] university students are aware of study abroad opportunities, only $51 \%$ of college students are" (35). For example, Douglas College in British Columbia noted in its international strategic planning that students "indicated that internationalization is vague and lacks meaning" and that " $59 \%$ of students surveyed were unclear on what internationalization was $69 \%$ see lack of funds as the key deterrent to study abroad." This final point is supported and reiterated by virtually all of the colleges.

Most of Canada's second-tier institutions have international strategies whereby, to the best of their abilities and resources, they seek global opportunities to enhance their reputations as well as opportunities for student and staff growth, and the furtherance of ties with local and global business communities. They generally recognize and value the unique contributions international students make to their mostly diverse and multicultural communities. The number of international students who have chosen to enrol in college programs has increased significantly in recent years and continues to grow. International student recruitment thus remains at the fore of 
strategies and activities, as international student tuitions provide an integral source of revenue for second-tier institutions, in that these tuitions often fund the balance of the internationalization strategy as well as provide fiscal relief to other centres on campus; colleges reinvest this revenue to provide overall educational advancements for the entire student body, as well as in facility improvements. This situation is substantially different from the Israeli one, where international students comprise the least developed branch of internationalization at second tier institutions.

Resourcing and mandate issues do lead to challenges of policy and implementation of internationalization strategies. Even so, the Canadian second-tier system can boast many accomplishments in terms of rapid growth and deep engagement internationally in many of the hallmarks of internationalization. ACCC runs an annual awards program recognizing excellence and leadership in the international arena for colleges; within British Columbia, the British Columbia Centre for International Education (BCCIE) offers its own internationalization awards, many of which have been granted to colleges. These strategic moves are intended to encourage further growth and recognition of internationalization activities in the traditional academic and vocational mandate areas of its 'second-tier' stakeholders. Indeed, internationalization's link to Canadian economic competitiveness has been recognized, alongside an appreciation that possessing knowledge and the ability to apply it in a global arena are critical to personal and societal advancement. Axiomatically, internationalization is not just about competitiveness, but also plays a strong role in promoting inter-cultural understanding and the spread of human rights and democracy, especially in a country such as Canada that is dependent upon global migration patterns to grow its population and economy.

The challenge moving forward for Canada's second-tier institutions lies in the successful bridging between their traditional mandate for local community service and business and industry engagement, on the one hand, and the recognition that what was once local is now global, even for resource-based economies common in Canada, on the other. Institutional strategies must begin to reflect the fact that, encouraging and supporting local industry and local economy must happen on a global stage, that the economy is now global. Strategic outcomes need to reflect the fact that in order for graduates to engage in the new economy, their schooling must prepare them on the many levels that sound international education and training can provide.

\section{Discussion and Conclusion}

Our comparative overview of second-tier institutions of higher education and their internationalization in Israel, the Netherlands, and Canada yields the following insights:

- The state of internationalization of second-tier institutions in the three countries is as diverse as the role, size, and position of these institutions in the overall higher education sector. In Canada, despite their unique characteristics, they 
play a more similar role to that of the university sector. In Israel, these colleges direct their internationalization efforts primarily as a tool in their struggle towards becoming a university. In the Netherlands, universities of applied sciences lack their own vision and strategy and mainly follow the approach that their 'big brothers,' the research universities, dictate - even if such decisions are not in their direct interest. Moreover, it seems that each of the countries' institutions act on a different arena in their internationalization efforts, with a focus on intercultural dimension in Israel, international students' inward movement in Canada, and curricular internationalization in the Netherlands.

- Second-tier institutions are generally inclined to look towards research universities in setting their agendas, tending to emulate these institutions rather than to construct on their own strengths and opportunities. This general trend within this sector appears to be true particularly regarding internationalization.

- Second-tier institutions stress the opportunities of their applied focus and strong relation to professional fields, compared to research universities. The professional fields require graduates with hard and soft skills, which these institutions can provide, in addition to applied research. Bringing the international and intercultural dimension into these hard and soft skills and strengthening applied research will make these institutions and their graduates better skilled for a global workforce.

- Second-tier institutions underestimate the potential for partnership with counterparts abroad. While successful international partnerships between second-tier and research universities are abundant, for instance in the health sector and other sectors where research universities and second-tier institutions are complementary, unexplored potential for international partnership remains as well. Instead of predominantly seeking out partnerships with research universities, second-tier institutions should cooperate more closely across borders and identify their similarities and complementarities in applied research and in developing a global workforce.

The three country case studies of second-tier institutions and their internationalization situation and context provide an initial insight into a large group of higher education institutions and their international dimensions. As ever-growing numbers of students start their studies at second tier higher education institutions, the need to prepare them for the globalized and dynamic world becomes more urgent (Green 2007). Further research is needed on other countries with second-tier higher education institutions. In the US, greater attention is being focused on the internationalization of community colleges, where a comparatively large knowledge base exist (see the recent reviews and special issues analyzing the internationalization trends in community colleges) ${ }^{3}$; while in other countries most of the research efforts are

\footnotetext{
${ }^{3}$ For Example, the journal New Directions for Community Colleges dedicated a Special Issue to Community Colleges in Global Context (2013, Issue 161); The Community College Journal for Research and Practice dedicated a Special Issue to Internationalization Efforts of Community Colleges $(2014,38,8)$.
} 
devoted to internationalization of universities. A more profound understanding of their international dimensions, obstacles and opportunities will add insight regarding the internationalization of this important conglomerate of institutions of higher education, thereby shedding light on internationalization's broader evolution.

Open Access This chapter is distributed under the terms of the Creative Commons Attribution Noncommercial License, which permits any noncommercial use, distribution, and reproduction in any medium, provided the original author(s) and source are credited.

\section{References}

ACCC, Association of Canadian Community Colleges. (2010). Internationalizing Canadian Colleges and Institutes: The First Report on International Education and Mobility. Retrieved June 2010, from http://www.accc.ca/ftp/pubs/studies/201006internationalizationreport.pdf.

Aerden, A., De Decker, F., Divis, J., Frederiks, M., \& Wit, H. (2013). Assessing the internationalisation of degree programmes: Experiences from a Dutch-Flemish pilot certifying internationalisation. Compare: A Journal of Comparative and International Education, 43(1), 56-78.

Altbach, P. G., \& Knight, J. (2007). The internationalization of higher education: Motivations and realities. Journal of Studies in International Education, 11(3-4), 290-305.

Arum, R., Gamoran, A., \& Shavit, Y. (2007). More inclusion than diversion: Expansion, differentiation, and market structure in higher education. In R. Arum, A. Gamoran, \& Y. Shavit (Eds.), Stratification in higher education-a comparative study (pp. 1-35). Stanford: Stanford University Press.

Ayalon, H., \& Yogev, A. (2006). stratification and diversity in the expanded system of higher education in Israel. Higher Education Policy, 19(2), 187-203.

Beerkens, E., Branderburg, U., Evers, N., Leichsenring, H., \& Zimmermann, V. (2010). Indicator projects on internationalization-approaches, methods and findings. Brussels: European Commission.

Bond, S. (2009). World of learning: Canadian postsecondary students and the study abroad experience. Ottawa: Canadian Bureau for International Education.

Breemer, L., \& Waechter, B. (1999). Introduction. In B. Waechter (Ed.), Internationalisation in European non-university higher education. ACA Papers on international cooperation in education (pp. 11-18). Bonn: Lemmens.

Coelen, R. (2014). A Revamped Vision for International Education. University World News, Issue 329, July 18, 2014.

Cohen, A., Yemini, M., \& Sadeh, E. (2014). Web-based analysis of internationalization in Israeli teaching colleges. Journal of studies in International Education, 18(1), 25-44.

De Wit, H. (2002). Internationalization of higher education in the United States of America and Europe: A historical, comparative, and conceptual analysis. Westport, CT: Greenwood Press.

De Wit, H. (2011). Law of the stimulative arrears? Internationalisation of universities of applied sciences, misconceptions and challenges. In H. De Wit (Ed.), Trends, issues and challenges in internationalisation of higher education (pp. 7-23). Amsterdam: CAREM.

De Wit, H. (2012). Crisis in Dutch Universities of applied sciences. International Higher Education, 69, 27-28.

De Wit, H. (2013a). Internationalization of higher education, an introduction on the why, how and what. In H. De Wit (Ed.), An introduction to higher education internationalisation (pp. 13-46). Milan: Università Cattolica University Press Vita e Pensiero, Centre for Higher Education Internationalisation (CHEI), UCSC. 
De Wit, H. (2013b). Rethinking the concept of internationalisation. In Going global: identifying trends and drivers of international education (pp. 213-218). London: Emerald Group Publishing.

Deardorff, D., De Wit, H, Heyl, J., \& Adams, T. (2012). The SAGE handbook of international higher education. Thousand Oaks, CA: Sage.

Deardorff, D., \& Jones, E. (2012). Intercultural competence: An emerging focus in international higher education. In D. Deardorff, H. De Wit, H. J. Heyl, \& T. Adams (Eds.), The SAGE handbook of international higher education (pp. 283-303). Thousand Oaks, CA: SAGE.

Egron-Polak, E., \& Hudson, R. (2014). Internationalization of higher education: Growing expectations, essential values. Paris: IAU 4rd Global Survey Report ed., IAU.

Green, M. F. (2007). Internationalizing community colleges: Barriers and strategies. New Directions for Community Colleges, 2007(138), 15-24.

HanzeConnect. (2008). Globalisering, MKB en het hoger onderwijs. Verkennend onderzoek naar de internationalisering van het MKB in Noord-Nederland en de rol van de Hanzehogeschool: Groningen.

Harder, N. J. (2010). Internationalization efforts in United States community colleges: A comparative analysis of urban, suburban, and rural institutions. Community College Journal of Research and Practice, 35(1-2), 152-164.

Hudzik, J. (2011). Comprehensive internationalization. Washington, DC: NAFSA.

International Association of Universities. (2012). Focus, rethinking internationalization. In IAU Horizons (Vol. 17-18, no. 3-1), February/March 2012. Paris: International Association of Universities.

Knight, J. (2004). Internationalization remodeled: Definition, approaches, and rationales. Journal of studies in international education, 8(1), 5-31.

Kyvik, S. (2002). The merger of non-university colleges in Norway. Higher Education, 44(1), 53-72.

Leggott, D., \& Stapleford, J. (2007). Internationalisation and employability. In E. Jones \& S. Brown (Eds.), Internationalising higher education (pp. 120-134). Oxon, U.K: Routledge.

Manns, D. (2014). Redefining the role, scope, and mission of community colleges in an international context. Community College Journal of Research and Practice, 38(8), 705-709.

Marginson, S. (2007). Global university rankings: Implications in general and for Australia. Journal of Higher Education Policy and Management, 29(2), 131-142.

Maringe, F. (2009). Strategies and challenges of internationalisation in HE: An exploratory study of UK universities. International Journal of Educational Management, 23(7), 5.

Oplatka, I. (2002). Implicit contradictions in public messages of "low-stratified" HE institutions: The case of Israeli teacher training colleges. International Journal of Educational Management, 16(5), 248-256.

Raby, R. L., \& Valeau, E. J. (2007). Community college international education: Looking back to forecast the future. New Directions for Community Colleges, 2007(138), 5-14.

Romano, R. M. (2002). Internationalizing the community college. Washington: Community College Press.

Shavit, Y., Arum, R., \& Gamoran, A. (2004, August). Expansion, differentiation and stratification in higher education: A comparative study of 15 countries. Annual Meeting of the American Sociological Association, San Francisco.

Stier, J. (2004). Taking a critical stance toward internationalization ideologies in higher education: Idealism, instrumentalism and educationalism. Globalisation, Societies and Education, 2(1), 83-97.

Stromquist, N. P. (2007). Internationalization as a response to globalization: Radical shifts in university environments. Higher Education, 53(1), 81-105.

Teichler, U. (2004). The changing debate on internationalisation of higher education. Higher Education, 48(1), 5-26. 
Van der Wende, M. C. (1999). Internationalisation of the Curriculum. Which are the challenges for the new higher education institutions. In B. Waechter (Ed.), Internationalisation in European non-university higher education. ACA papers on international cooperation in education (pp. 209-218). Bonn: Lemmens.

VSNU and Vereniging Hogescholen. (2014). Gezamenlijke Visie Internationaal. VSNU en Vereniging Hogescholen: Den Haag.

Waechter, B. (1999). The country reports. Some first observations. In B. Waechter (Ed.), Internationalisation in European non-university higher education (pp. 181-190). ACA Papers on International Cooperation in Education, Bonn: Lemmens.

Yemini, M. (2014). Internationalization in Israel. Jerusalem: Taub Center.

Yemini, M., \& Ben-Artzi, Y. (2013). Mind the gap: Bologna process implementation in Israeli higher education system. Dapim, 55, 177-197.

Yemini, M., Holzman, V., De Wit, H., Stavans, A., Fadila, D., \& Sadeh, E. (2014a). The Drive to Internationalize: Perceptions and Motivations of Israeli College Directors. Higher Education Policy (forthcoming).

Yemini, M., Holzmann, V., Fadilla, D., Natur, N., \& Stavans, A. (2014b). Israeli college students' perceptions of internationalisation. International Studies in Sociology of Education, 24(3), 304-323. 